\title{
THE DEVELOPMENT AND THE EFFECTIVENESS OF ENGLISH E-LEARNING
}

\author{
Noni Agustina ${ }^{1}$, Nugroho Budhisantosa ${ }^{2}$ \\ ${ }^{1}$ Education and Teacher Training Faculty, Esa Unggul University, Jakarta, Indonesia \\ e-mail: noni@esaunggul.ac.id \\ ${ }^{2}$ Computer Science Faculty, Esa Unggul University, Jakarta, Indonesia \\ e-mail: nugroho.budhisantosa@esaunggul.ac.id
}

\begin{abstract}
Abstrak
Di abad ke 21 ini, guru dituntut untuk memiliki literasi digital. Mereka harus mampu mengintegrasikan teknologi dalam proses pembelajaran. Literasi digital tersebut sudah dilakukan oleh salah satu guru SMP di Jakarta. Guru tersebut mencari bahan ajar dari internet namun menemui masalah dalam menyesuaikan dengan materi ajar yang sesuai dengan karakteristik dan kebutuhan siswa. Oleh karena itu, studi ini perlu dilakukan untuk mengambarkan secara mendalam proses pengembangan pembelajaran berbasis digital yang disebut dengan e-learning yang sesuai dengan kebutuhan siswa dan menguji efektivitas e-learning tersebut. Studi ini menggunakan metode penelitian dan pengembangan dengan pendekatan kualitatif dan kuantitatif dengan partisipannya adalah guru dan siswa SMP kelas satu. Hasil studi menunjukkan bahwa pengembangan e-learning ini menggunakan PHP, Framework Bookstrap, MySQL, aplikasi untuk membuat gambar dan video animasi. Hasil studi juga menunjukkan bahwa pembelajaran Bahasa Inggris dengan menggunakan e-learning lebih efektif dibandingkan dengan tidak menggunakan e-learning. Perbedan hasil belajar keduanya sebesar $5.53 \%$ dan berbeda secara signifikan (Sig.2-tailed $0.011<0.05)$. E-learning diharapkan dapat digunakan sebagai media pendukung dalam pembelajaran Bahasa Inggris.
\end{abstract}

Kata kunci: Pengembangan e-learning, literasi digital, pembelajaran bahasa Inggris

\begin{abstract}
In the twenty first century, teachers are required to have a digital literacy skill. They must be able to integrate technology in learning process. It was already conducted by a teacher in one of public junior high schools in Jakarta. She searched the materials from the internet but she had a problem to adjust the learning materials to her students' needs and characteristics. Therefore, this study was undertaken to explore deeply how to develop e-learning in English class based on her students' needs and characteristics and examined its effectiveness. This study employed research and development methodology with qualitative and quantitative approach. The participants were an English teacher and the first graders of junior high school. The result showed that this e-learning consisted of listening, reading, and grammar used PHP, Framework Bookstrap, MySQL, and some software to make the images and some animated videos. The result also showed that the learning English using e-learning was more effective than without it. The difference of mean was $5.53 \%$. It was also different significantly between them (Sig.2tailed $0.011<0.05$ ). It is expected to contribute as supplemental learning media in English learning process.
\end{abstract}

Key words: E-learning development, digital literacy, English learning 


\section{INTRODUCTION}

The proliferation of information communication and technology grows rapidly nowadays. That phenomenon can be seen from the high use of cell phone and the internet around the world. 3.15 billion people use the cell phone and 3 billion people use the internet (Koller, Foster \& Wright, 2008; Kende, 2014). Internet is highly demand in our life (Solak \& Cakir, 2015). The use of the internet in Indonesia increases 100 percent each year (Effendi \& Zhuang, 2005). It provides various information needed. It influences many aspects in human life. Solak and Cakir (2015) state one of them is education world. It influences the teaching and learning process in the class (Cai, 2012; Tuncay \& Uzunboylu , 2015). When the previous observation was conducted, one of teachers at public junior high school in West Jakarta, Indonesia used the laptop and projector as well the speaker when teaching English in the class. She taught her students using video downloaded from the internet. Sometimes, she used the online learning such as Edmodo to teach her students. She was a portray of a teacher in the twenty first century that she had the digital literacy. The teacher needs the ability to use the information and communication technology in their classroom such as the internet use (Chou \& Chen, 2016). The Ministry of Education and Culture of Republic of Indonesia also determine the national literacy movements. One of them is the digital literacy. It means that Indonesian government has been supporting schools to implement the digital literacy. Nowadays, they applied computerassisted test for the national test in some schools for some areas around Indonesia.

Based on the previous interview, even though the teacher integrated the technology in teaching English in the classroom, she had problem to adjust the material she found from the internet to meet her students' needs and characteristics. She also had difficulty to find resources such as listening. Although, information and technology center of the Ministry of Education and Culture provides the elearning in website (http://edukasi.kemdikbud.go.id/), it cannot be accessed because it always comes up "file or directory not found' command. The elearning also has not been much more developed in Indonesia (Setyowati,2009; Turino et al., 2009). To address those problems, this study is important to undertaken by developing English elearning. There are some various terminologies used addressing the $\mathrm{e}$ learning: web-based learning, online learning, computer-based learning or computer-based instruction. Morrison (2003) and Aparicio et al. (2016) name it online learning. Even though it has different names, it is used in teaching and learning process involving the technology such as computer network (internet/ intranet) or multimedia (Aparicio et al., 2016; Rymanova et al., 2015; Mohammadi et al., 2011). It has some functions: supplementary and substitution functions. Supplementary function means that it can be combined with the conventional learning which emphasizes on face-to-face learning in the classroom. It is used to enrich the learning process. On the other hand, Turino et al. (2009) urge that substitution function means using e-learning fully in learning process. A study showed that the e-learning and traditional education are still used together. They complete each other in order to reach the educational result (Kim \& Santiago, 2005).

Khodabandelou \& Samah (2012) reveal that some studies found that the elearning was more effective than traditional instruction. It has some advantages. It can support the learning process (Solak \& Cakir, 2015; Triyono, 2014; Muis et al., 2012; Munir \& Prabowo, 2014). It gains the academic achievement, motivation, performance and attitudes (Rymanova et al., 2015; Mohammadi et al., 2011; Khodabandelou \& Samah, 2012). It facilitates the teachers to provide learning materials and they ask their students to accomplish and submit the assignments or exercises. The learning process is also fun, interactive and effective by using it (Muis et al., 2012). It provides the flexibility of time, place, learning speed, instructional standardization and effective instructional. The slow students can learn the material or tutorial provided in the e-learning. It can help them (Effendi \& Zhuang, 2005). The 
students also can learn autonomously (Rymanova et al., 2015).

The previous studies were undertaken by some researchers in developing the elearning. Yaniawati and Muis et al. (2012) conducted the e-learning for mathematic class. Munir dan Prabowo (2011) developed the e-learning using SMS Joomla for vocational high school students in Bantul, Indonesia which its content was about computer sciences. Turino et al. (2009) developed e-learning for teaching listening skill for senior high school (SMA 4) in Semarang, Indonesia. He designed it using Adobe Flash Professional CS3 in swf format. Setyowati (2009) focused on reading skill for senior high school students. Sutisna (2013) developed the e-learning for teaching grammar class at English Class Department, Pakuan University, Indonesia. It's a useful tool for the lecturer too when teaching grammar. Siswono and Liona (2010) also developed the e-learning which emphasized on phonology, syntax, semantic, and pragmatic. They provided stories with proper grammar. Solak \& Cakir (2015) developed the course of e-learning consisted of basic English skills which contain animation and interactive presentation for higher education level. The students also were able to discuss with their teachers in a synchronized way. Rymanova et al. (2015) developed e-course using Moodle as the Learning Management System which its contents were lexical, grammar, and speaking skill. From the studies, it could be concluded that the elearning for English class concerning on some English skills. It is developed for senior high school level and mostly for higher education level (Xiangqian \& Fuqing, 2012). In USA, almost 90 percent of universities use it (Effendi \& Zhuang, 2005) and in Korea 70 percent (Josic et al., 2011) [23]. It had not been found for junior high school level. Thus, this study develops listening, reading, and grammar for English learning at junior high school level especially for first grade. The study aims to explore and describe deeply the development of the English the e-learning by applying a need analysis. It is required to design the instructional material for the e-learning. Furthermore, this study also examines the effectiveness of the e-learning.

\section{METHOD}

This study employed research and development methodology. Its aim was to yield a product (Sugiyono, 2012). It had many kinds of model used. Those models had different steps and processes (Cai, 2012). This study used Gall and Borg model. The process consisted of conducting need assessment, planning (identifying skills that will be learnt, generating the objective and learning activities, and having expert's validation), revising the products referring to the feedback given by the experts, conducting the field testing of the product to three students and teacher, and revising the product based on students and teachers' feedback. After it was validated and tested to three students, it was implemented to a class. Then it was examined by applying experimental research design.

This study was conducted from January to June 2017. The participants of this study were first graders and an English teacher of 89 Junior High School in West Jakarta, Indonesia. Interviewing the teacher was undertaken to obtain the data what she and her students needed. The document analysis (the syllabi) was also required to write the objective so it could be used a supporting data. The instruments used to validate media and content of elearning were given to the experts. The questionnaire for teacher and students are also provided to get their feedback. The students' scores (using e-learning and without e-learning) were used to analyze whether there was the difference between two of them or not.

\section{RESULT AND DISCUSSION}

Based on the need analysis, students required to learn listening and reading skills which focused on descriptive texts. Those descriptive texts had some themes such as people, animal, place, thing, and occupation. The materials referred to the 2013 curriculum. Not only listening and reading skills, they were also necessary to learn grammar such as simple present tense, adjective, adverb, and preposition. After analyzing the needs, the next steps 
were making the e-learning content, determining the name of e-learning website, making the logo, making the login for the students and teacher (administrator), developing English Gate by using PHP, Framework
Bootstrap, and MySQL, making Entity Relationship Diagram (ERD), inputting the content into database system, hosting all database systems created in mini Raspberry Pi 3, sending English Gate as English e-learning to be validated, and testing English Gate to three students.

\begin{tabular}{|c|c|}
\hline is userlD : int(11) unsigned & 目 hasil1: varchar(255) \\
\hline (1) nama lengkap : varchar(255) & (1) hasil2 : varchar(255) \\
\hline 自 class_murid : varchar(100) & (⿴) hasil3 : varchar(255) \\
\hline \# nomor_induk : int(11) & (1) hasil4 : varchar(255) \\
\hline 自 username : varchar(255) & (⿴) hasil5: varchar(255) \\
\hline \multicolumn{2}{|c|}{ Fig. 1. Example of ERD } \\
\hline
\end{tabular}

The content of e-learning consisted of listening, reading, and grammar. The listening contained the audio by recording an American native speaker's voice. It provided the audio with the animation, vocabulary (English-Indonesia), and multiple-choice questions. When students clicked the words in vocabulary, they had sound. The reading provided some texts with the sound, pictures, vocabulary, and short-answer questions. The students had to type the answer in the box provided. The grammar had the animated video which aimed to help the students to learn adjective, adverb, preposition and simple present tense. After they watched the animated video, they could play the game by accomplishing some exercises related to the grammar they learnt before. The exercises were in fill-in-the blank format. The students also could see their result and the answer key after they finished answering the exercises. The animations were created by using some software such as Adobe Flash and Adobe Illustrator.

English Gate was chosen as the name of the English e-learning. The logo was created using Adobe Illustrator. It provided login for the students and teacher (administrator). Students' login could be used to learn the material, do the exercises and see their scores. Administrator's login could be used to see the students' score, assess her/his students' score, register students' data, edit and delete the questions and answers. It used PHP as a back-end, Framework Bootstrap as frontend and MySQL as a database system. Entity Relationship Diagram (ERD) was used to describe the logical structure of database.

The contents were inputted into the database system. They were the homepage of English Gate consisting of home, login, about us, listening, reading, and grammar; username and password of administrator for login in the administrator dashboard; the questions by clicking 'manage question' in the administrator dashboard. All those data base systems created were hosted in mini Raspberry Pi 3 that functioned as web server. Thus, the IP address of the web server was 192.168.1.200. 


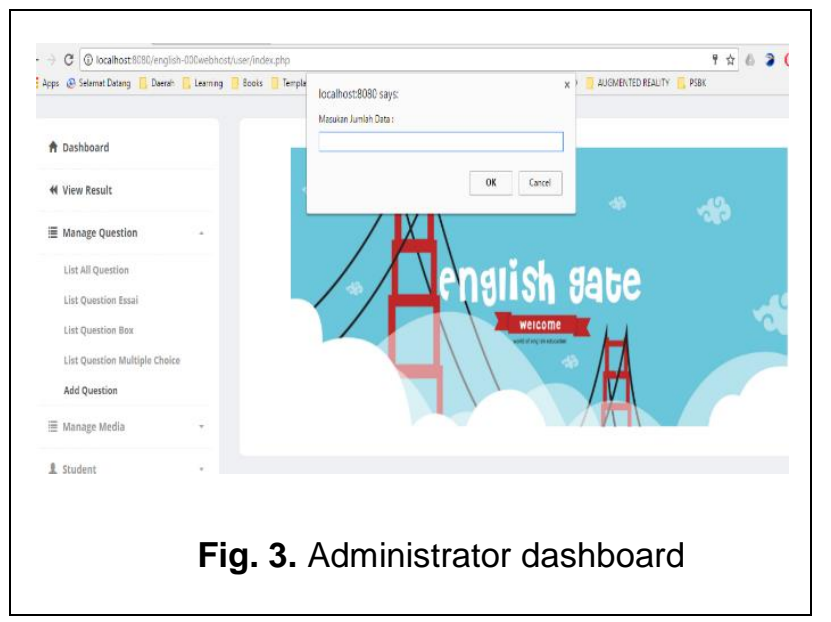

English Gate was sent to two experts and teacher to validate its media and content. The result showed that the content was good and the content expert and the teacher did not give any suggestion about the content. On the other hand, the media experts gave some feedback. The feedback was the homepage display should be added and provided the manual how to use English Gate. Referring to those suggestion, it was revised and sent back to be validated again. The second validation showed the e-learning deserved to be applied and tested to some students.

These results of this study were not fully similar to the previous study. The development of the e-learning (English gate) consisted of login, homepage, interactive learning material (listening, reading and grammar) consisting of animated video, and quizzes with the feedback. The previous study found that the components of the e-learning contents were varied. This result study showed that Morrison developed it consisting of register, login, personal profile, material consisting of pre-assessments, texts, pictures, simulations, interactive exercises, downloaded materials, quizzes, bookmarks, post-assessments, and feedback (Muis et al., 2012). It's a little bit different from Morrison, Munir and Prabowo developed their e-learning content comprising curriculum, syllabus, materials and tests. Turino, et al. also provided login, homepage, syllabi, evaluation, and online consultation and chatting forum. Login was

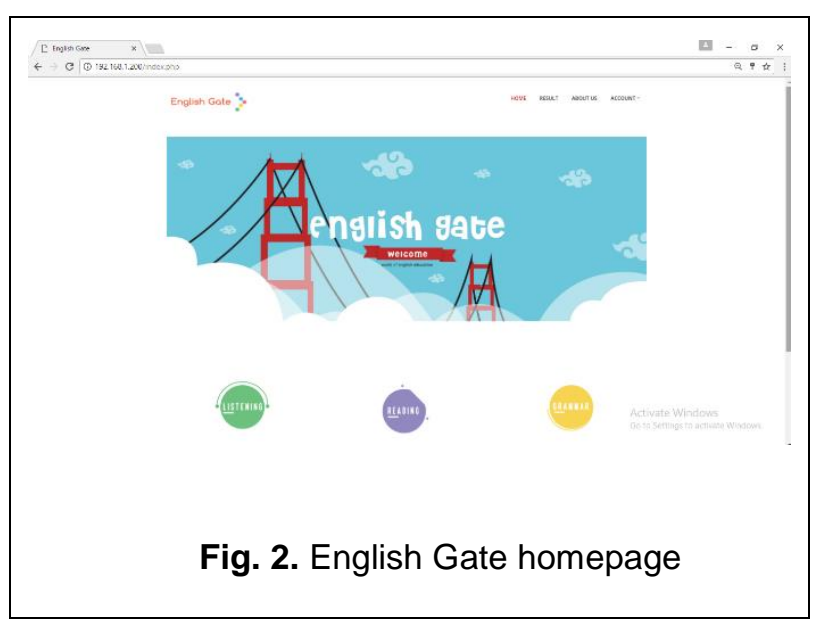

for the administrator, students, and teachers. The homepage consisted of main menu, register, and learning menu which offered downloaded material for students and teachers. The materials were in audio, Microsoft Word, Microsoft PowerPoint, PDF, and animation format. The listening materials developed used Adobe Flash Professional CS3. The syllabi were also provided, if the teachers wanted to delete or add them, they could do it. The evaluation comprised the questions and answers with various format such as multiple choice and true-false. The online consultation and chatting forum were designed to facilitate the students' interaction and participation. Almost similar to the previous researchers, Siswono dan Liona developed their e-learning consisting of login, learning plan, lesson, story, exercise, and dictionary. The learning plan provided a year learning planning. The lessons were the materials given to the students. The story feature consisted of animations with different themes. The dictionary was useful for the students to find the meaning of words. Rymanova et al. developed the e-learning, namely e-course, which consisted of the general data (teachers' personal data), unit feature (instructional unit, materials such as vocabulary and grammar, glossary, activities and supplementary resources from internet, and assessment feature. The materials were video, animation, text or images. They also provided Forum, Chat, and Wiki which facilitated students to 
interact with their instructors or teachers. The tests of units had some variations such as multiple choice, matching, short answer and other forms.

English Gate was tested to three students. They were observed by recording them when they used it. The result showed that they could use it well. Then they were given a questionnaire sheet to know their response in using it. All of them urged that they were happy to use it and more understand to learn English. The vocabulary also helped them to understand the meaning of words. Some of them gave suggestion to improve the assessment of reading because they thought their answers were correct but they had unsatisfying scores. Therefore, the teacher had to rechecked their reading answers and scores. Some studies showed that the content of the e-learning was not absolutely same one another. The important thing was it gave a significant impact for the students. It could be accessed autonomously by the students, flexible use, effective and efficient. Siragusa (2000) revealed that the main components in online learning were content, interaction, feedback, and interface design. The content had to align to the purpose and students' ability. The interaction referred to the communication between the students and teachers or instructors. The feedback referred to the teachers' comment or suggestions given to the students both individually or in group. The interface referred to easy navigation that could help and respond the students. The use of image, color, sound, animation could entice the students (Khodabandelou \& Samah, 2012)

After the e-learning deserved to apply, it was examined by using the experimental research design which tested two groups, the class that used the e-learning (class $7 \mathrm{~F})$ and the class without e-learning $(7 \mathrm{H})$. Both of two classes studied the same topics.

Before conducting statistical test, test of normality and homogeneity of variance were undertaken. The result found that the significance value of e-learning group is more than $0.05(0.080>0.05)$. It indicated that it had normal data distribution. The data of the non-e-learning group was also normal (the significance value was more than 0.200 . It could be seen in the table 1 .

Table 1. Test of normality

\begin{tabular}{|c|c|c|c|c|}
\hline & \multirow[b]{2}{*}{ Group } & \multicolumn{3}{|c|}{ Kolmogorov-Smirnov ${ }^{a}$} \\
\hline & & Statistic & df & Sig. \\
\hline \multirow[t]{2}{*}{ Score } & E-learning group & .151 & 30 & .080 \\
\hline & Non e-learning group & .109 & 30 & $.200^{*}$ \\
\hline
\end{tabular}

The variance of the group was not equal because the significance value is less than $0.05(0.006<0.05)$. If the variances were not equal, "equal variances not assumed" was used for the result of independent samples t-test. The data could be seen in table 2.

Table 2. Test of normality

\begin{tabular}{|r|r|r|r|}
\hline \multicolumn{4}{|c|}{ Test of Homogeneity of Variances } \\
Score \\
\begin{tabular}{|r|r|r|r}
\hline $\begin{array}{c}\text { Levene } \\
\text { Statistic }\end{array}$ & df1 & df2 & Sig \\
\hline 8.202 & 1 & 58 & .006 \\
\hline
\end{tabular}
\end{tabular}

The independent sample t-test was used to determine whether the learning result of e-learning group (grade 7F) is different significantly from non-e-learning group (grade $7 \mathrm{H}$ ). The result found that the learning score between students who used e-learning and those used without it was different. The difference of mean was $5.53 \%$. Furthermore, the significance value (Sig.2-tailed of equal variances not assumed) was less than $0.05(0.011<$ $0.05)$. It indicated that null hypothesis was rejected which it revealed that there was a difference in learning score between elearning group and non-e-learning group. It could be interpreted that the use of elearning was more effective than without it. The statistical analysis could be seen in the table 3.

This study found that the use of the elearning in English learning for first graders was more effective than conventional method (without e-learning). The students were also enthusiastic when using it in learning process. The previous studies conducted were also similar to this study. Yaniawati and Muis et al. conducted the e- 
learning for mathematic class and the result showed that it gave the positive impact for the students' learning. Turino et al. developed e-learning and they found that the students' listening skills improved and the students were happy when using it. Setyowati found her students' reading skill increased when using the e-learning. Sutisna, Siswono and Liona's research also showed that students' understanding on grammar and their motivation increased when they used the e-learning.

Even though the result of this study was similar to the previous studies, this study was different in content. This study emphasized on listening, reading, and grammar for first graders of junior high school.

\section{CONCLUSION AND RECOMMENDATION}

English Gate, the English e-learning is not fully similar to the other e-learning. Its components consist of login, homepage, interactive learning material (emphasizing on listening, reading, and grammar) consisting of video animation, quizzes with the answer key. The materials referring to the need analysis and 2013 curriculum concerning on descriptive text with various themes such as people, animal, place, thing, and occupation. English Gate is developed using $P H P$, Framework Bootstrap, MySQL, Entity Relationship Diagram (ERD). The contents were inputted into database system and hosted into mini Raspberry Pi 3 as web server.

English Gate is examined its effectiveness by comparing two classes (elearning group and non-e-learning group). The result shows that the difference is found between two of them. The mean of e-learning group's score is higher than non-e-learning group. The different of mean is $5.53 \%$ It is different significantly. To conclude, the elearning is more effective than conventional one (without the e-learning).

Table 3. The independent sample t-test between e-learning group and non-e-learning group

\begin{tabular}{|ll|r|r|r|c|}
\hline \multicolumn{1}{|c|}{ Group Statistics } \\
\hline Gcore & E-learning group & \multicolumn{1}{|c|}{$\mathrm{N}$} & Mean & Std. Deviation & $\begin{array}{c}\text { Std. Error } \\
\text { Mean }\end{array}$ \\
& Non e-learning group & 30 & 83.93 & 9.944 & 1.816 \\
78.40 & 5.679 & 1.037 \\
\hline
\end{tabular}

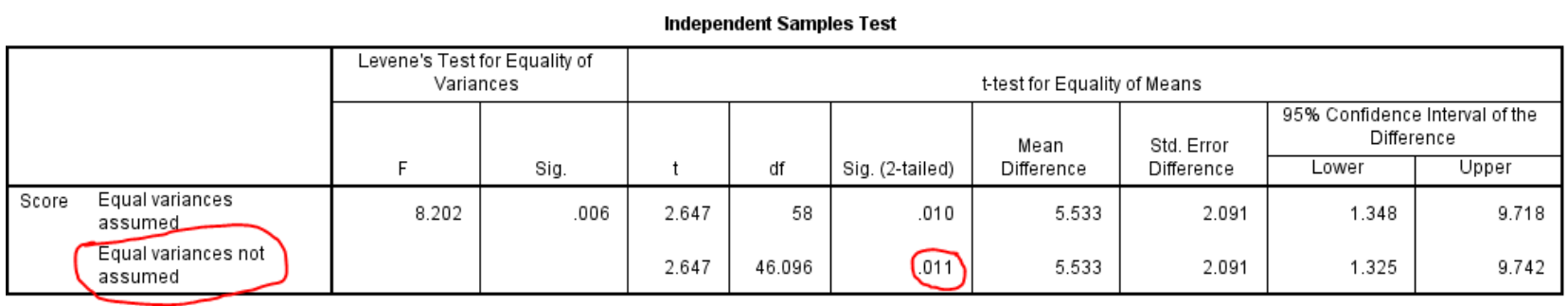

This study only focuses on first grade level. The further research is required to conduct for the next level of English Gate development.

\section{ACKNOWLEDGEMENT}

This study is supported by grant of Ministry of Research, Technology and Higher Education of the Republic of Indonesia.

\section{REFERENCES}

Aparicio, M., Bacao, F., Oliveira, T., Aparicio, M., Bacao, F., \& Oliveira, T. 2016. An E-learning Theoritical Framework. Journal of Educational Technology \& Society, 19(1), 292307.

Cai, H. 2012. E-learning and English Teaching. Procedia IERI, 841-846.

Chou, H. L., \& Chen, C. H. 2016. Beyond Identifying Privacy Issues in Elearning Settings- Implications for Instructional Designers. Computers 
and Education, 103, 124-133. https://doi.org/10.1016/j.compedu.201 6.10.002

Effendi, Empy dan Hartono Zhuang. 2005. E-learning Konsep dan Aplikasi. Yogyakarta: Andi

Hussin, Husnayati. Bunyarit, Fatimah. Hussein, R. 2009. Instructional Design and E-Learning: Examining Learners' Perspective in Malaysian Institutions of. Campus-Wide Information Systems, 26(1), 4-19. https://doi.org/10.1108/10650740910 921537

Josic, D., Delic, D., Rasulic, N., Stajkovic, O., Kuzmanovic, D., Stanojkovic, A., \& Pivic, R. 2011. The Dimensions of ELearning Quality: From the Learner's Perspective. Educational Technology Research and Developent, 59, 445464. https://doi.org/10.1007/sl

Kende, M. 2014. Internet Society Global Internet Report 2014. Internet Society, 146. Retrieved from http://www.internetsociety.org

Khodabandelou, R., \& Samah, S. A. A. 2012. Instructional Design Models for Online Instruction: From the Perspective of Iranian Higher Education. Procedia - Social and Behavioral Sciences, 67, 545-552. https://doi.org/10.1016/j.sbspro.2012. 11.359

Kim, C.-J., \& Santiago, R. 2005. Construction of E-Learning Environments in Korea. Educational Technology Research and Development, 53(4), 108-115.

Koller, A., Foster, G., \& Wright, M. 2008. Java Micro Edition and Adobe Flash Lite for Arcade-Style Mobile Phone Game Development: A Comparative Study. ACM International Conference Proceeding Series, 338(October), 131-138.

https://doi.org/10.1145/1456659.1456 675

Morrison, Don. 2003. E-learning Strategies. How to Get Implementation and Delivery Right
First Time. England: Wiley

Muis, dkk. 2012. Pelaksanaan Pembelajaran Berbasis E-Learning Bidang Studi Matematika Pada SMP Negeri 1 Magelang. Diunduh dari http://eprints.ums.ac.id/

Munir, Muhamad dan Korniawan Prabowo. 2011. Pengembang ELearning Berbasis Multimedia Sebagai Multimedia Center untuk Meningkatkan Kualitas Pembelajaran TKJ di SMK. Diunduh dari staff.uny.ac.id/

Mohammadi, N., Ghorbani, V., \& Hamidi, F. 2011. Effects of E-learning on Language Learning. Procedia Computer Science, 3, 464-468. https://doi.org/10.1016/j.procs.2010.1 2.078

Putra, Nusa. 2015. Reseach and Development. Penelitian dan Pengembangan: Suatu Pengantar. Jakarta: PT RajaGrafindo Persada

Rymanova, I., Baryshnikov, N., \& Grishaeva, A. 2015. E-course Based on the LMS Moodle for English Language Teaching: Development and Implementation of Results. Procedia - Social and Behavioral Sciences, 206(November), 236-240. https://doi.org/10.1016/j.sbspro.2015. 10.016

Setyowati. 2009. Implementasi ELearning Sebagai Media Ajar. Diunduh dari http://lib.ui.ac.id/

Siswono dan Yurika Liona. 2010. Perancangan E-learning dengan Pendekatan ADDIE Model (Kasus: Mata Pelajaran Bahasa Inggris-SD IPEKA Tomang). Jurnal ComTech. 1 (2), 300-308

Solak, E., \& Cakir, R. 2015. Language Learning Strategies of Language Elearners in Turkey. E-Learning and Digital Media, 12(1), 107-120. https://doi.org/10.1177/204275301 4558384

Sugiono. 2012. Metode Penelitian Kuantitatif dan Kualitatif dan $R \& D$. 
Bandung: Alfabeta

Sutisna, Entis. 2013. Model pembelajaran Grammar Berbasis Website. Diunduh dari http://digilib.upi.edu/

Triyono, M. B. 2015. The Indicators of Instructional Design for E- learning in Indonesian Vocational High Schools. Procedia - Social and Behavioral Sciences. https://doi.org/10.1016/j.sbspro.201 5.08.109

Tuncay, N., \& Uzunboylu, H. 2012. English Language Teachers' Success in Blended and Online E-Learning. Procedia - Social and Behavioral Sciences, 47, 131-137. https://doi.org/10.1016/j.sbspro.201
2.06.626

Turino, dkk. 2009. E-learning Bahasa Inggris Berbasis Web. Jurnal Teknologi Informasi, 5 (2).

Xiangqian, L., \& Fuqing, G. 2012. Development-Driven E-learning Education Model and Application in Teaching Information Technology. IERI Procedia, 2, 854-858. https://doi.org/10.1016/j.ieri.2012.0 6.182 